\title{
Decomposing Total Factor Productivity of Sudanese Sugarcane Factories (2000-2007)
}

\section{Mohamed OA* and Lubna MA}

University of Gezira, Wad Medani, Sudan

\begin{abstract}
This paper reports the measure of total factor productivity change (TFPCH) for the Sudanese sugarcane factories: An empirical analysis with reference to Sudanese sugar companies (Kenana, Gunied, New Halfa, Sinnar and Assalaya). Based on Data Envelopment Analysis Program (DEAP) Software Version 2.1, using model of inputoriented Malmquist indices of total factor productivity (TFP). Relevant secondary data were collected and analyzed to meet the stated objectives. This paper aimed to decompose TFPCH into two components: Technological change $(T E C H)$ and technical efficiency change $(E F C H)$ and the latter was further divided into scale efficiency change $(\mathrm{SEFCH})$ and pure efficiency change $(\mathrm{PEFCH})$. In the study on Sudanese sugarcane plants, the innovation was improving up and down of TECH over time. Scale efficiency operating in Kenana was remained constant return to scale, and total factor productivity was positive. For measuring the scale efficiency operating in Sudanese Sugar Company the results suggest that the scale efficiency was constant return to scale in Gunied and New Halfa compared to increased return to scale in Sinnar and Assalaya. The study recommended that the policy maker in the Sudanese Sugar Company and managers of other sugar factories should make effort to benefit from added value of sugar industry through downstream processes of sugarcane by-product such as molasses bagasse and filter cake, which could be utilized usefully for animal feed, energy and ethanol production.
\end{abstract}

Keywords: Productivity analysis; Sudanese sugar factories; Efficiency change; Technical change; Regression; Sudan

\section{Introduction}

The sugar commodity plays a significant role in national economy of Sudan. It produced locally to fill the gap of sugar consumption, saving hard currency, and improving the trade balance. Increasing export of sugar could also save hard currency and then refresh national economy. Sugar production had increased from 290,000 tons in 1990 to 756,000 tons in 2007 . Yield per feddan was only 2 tons of sugarcane, but now and after continuous efforts, it reached 48 tons of sugarcane in Kenana factory.

\section{Sugar schemes in Sudan}

Sudan is one of the Arab and African country with tremendous natural resources for food security, has a large area suitable for cane planting in addition to experience, knowhow and availability of labor. This study consisted of five sugar factories.

1-Kenana Sugar scheme (KSS): Kenana Sugar Company it is private sector the most important of which is Kenana sugar factory which is considered as one of the biggest sugar factories in the African and Arab countries

2- Sugar schemes under the Sudanese Sugar Company: Sudanese Sugar Company is public sector, it works according to 1925 private company law it consists of four factories:

1-Gunied Sugar Scheme (GSS), 2-New Halfa Sugar Scheme, 3-Sinnar Sugar Scheme and 4-Hajar Assalaya Sugar Scheme

\section{Problem statement}

Productivity is of interest to economists and policy makers, because productivity growth is a major source of economic growth and welfare improvement as shown in Table 1. Technical advance and technical efficiency change are two key factors to productivity growth, which are associated with different sources, and so different policies may be required to address them. Therefore, it is important to decompose productivity growth into these two components: Technical change and efficiency change. Despite problems associated with any industry, the sugarcane industry has performed well as it surpassed the target of the
Industrial Master Plan (IMP) in terms of total production and export revenue. In 2007, the total production of Sudanese sugar was 756.000 tons $[1,2]$.

Although the above performance gave a sense of satisfaction, there was reasonable apprehension that the industry would grind itself to stagnation, as it was unable to break away from its present narrow range of basic sugarcane raw production as shown in Table 2. Given the industrial development, together with the technological change and availability of raw materials, there was a vast potential for the industry to break off from its nutshell and go beyond basic sugarcane production to immediate and end use products. In order to take the full advantage of this potential, there was a need for the industry to address fundamental issues. One of the critical issues that could affect the future direction of the local sugarcane factories was the rising of local regional and global competition. World sugar balance is shown in Table 3. The Sudanese Sugar Company factories and Kenana Company had been able to develop rapidly due to their relative low costs of production and availability of cheap local raw materials. So, it is important to know whether this industry is competitive enough to face these local, regional and global challenges. The competitiveness of this industry over time could be measured by efficiency and productivity analysis from an applied perspective, measuring efficiency is important because this is the first step in a process that might lead to substantial resources saving [35]. These resource savings would have important implications on both policy formulation and factories management. In an economy where resources are scarce and opportunities for new technologies are limited, efficiency studies would show the possibility of increasing productivity

*Corresponding author: Mohamed OA, University of Gezira, Wad Medani, Sudan, Tel: (+249)511-84 16 23; E-mail: mosman@uofg.edu.sd

Received January 07, 2016; Accepted February 24, 2016; Published February 26, 2016

Citation: Mohamed OA, Lubna MA (2016) Decomposing Total Factor Productivity of Sudanese Sugarcane Factories (2000-2007). Int J Econ Manag Sci 5: 330 doi:10.4172/2162-6359.1000330

Copyright: () 2016 Mohamed OA, et al. This is an open-access article distributed under the terms of the Creative Commons Attribution License, which permits unrestricted use, distribution, and reproduction in any medium, provided the original author and source are credited. 


\begin{tabular}{|c|c|c|}
\hline Sites & Area (1000) feddan & Capacity (1000) tone \\
\hline White Nile & 165 & 340 \\
\hline Melut & 35 & 110 \\
\hline Mongala & 35 & 110 \\
\hline Rank & 67 & 200 \\
\hline Gelhak & 90 & 270 \\
\hline Rahad & 30 & 90 \\
\hline Gabal Awlia & 90 & 270 \\
\hline Total & 512 & 1380 \\
\hline
\end{tabular}

Table 1: The proposed sites for sugar production in Sudan.

\begin{tabular}{|c|c|c|c|c|c|}
\hline Country & Average 99-03 & $\mathbf{2 0 0 4}$ & $\mathbf{2 0 0 5}$ & $\mathbf{2 0 0 6}$ & $\mathbf{2 0 0 7}$ \\
\hline Sudan & 655.02 & 755.021 & 720.91 & 751 & 751 \\
\hline Syria & 90.7 & 105.96 & 95.5 & 117.6 & 115.52 \\
\hline Somalia & 22.14 & 22 & 23 & 23 & 23 \\
\hline Iraq A & 1.98 & 2 & 2 & 2 & 2 \\
\hline Lebanon & 15.62 & 1.9 & 3.75 & 3.75 & 3.75 \\
\hline Egypt & 1467 & 1524.05 & 1689.05 & 1689.05 & $1689.05 \mathrm{~A}$ \\
\hline Morocco & 510 & 508 & 500 & 409 & 450 \\
\hline Total & 2762.46 & 2918.931 & 3034.21 & 2995.4 & 3034.32 \\
\hline
\end{tabular}

Table 2: Raw sugar production in the Arab region in thousand tons (99-2007)

\begin{tabular}{|c|c|c|c|c|c|}
\hline Year & $\mathbf{2 0 0 5 / 0 6}$ & $\mathbf{2 0 0 6 / 0 7}$ & $\mathbf{2 0 0 7 / 0 8}$ & $\mathbf{2 0 0 8 / 0 9}$ & $\mathbf{2 0 0 7 / 0 8}$ \\
\hline Production & 150159 & 166.079 & 168.611 & 161.527 & 168.611 \\
\hline Consumption & 152626 & 156.942 & 162.241 & 165.801 & 162.241 \\
\hline Surplus/deficit & -2467 & 9.137 & 6.37 & -4.274 & 6.37 \\
\hline Import demand & 48086 & 48.74 & 45.948 & 49.621 & 45.948 \\
\hline Export availability & 48131 & 48.925 & 46.245 & 49.608 & 46.245 \\
\hline End stocks & 55507 & 64.387 & 70.533 & 66.272 & 70.533 \\
\hline Stocks/consumption ratio \% & 36.37 & 41.03 & 43.47 & 39.97 & 43.47 \\
\hline
\end{tabular}

Table 3: World sugar balances in thousand tons, raw value (2005/06-2008/09).

by improving efficiency. Estimates on the extent of the inefficiency could help decide whether to improve efficiency or to develop new technologies to increase industrial productivity. In policy arena, there is a continual controversy regarding the connection between factory size, efficiency and the structure of production [6]. Efficient plants are more likely to generate higher income and thus have a better chance of surviving and prospering. Therefore, it is pertinent to review the existing production structure and identify some critical parameters of the sugarcane factories with a view to sustaining the competitive edge of the industry to face regional and global competition. Sugar industry is one of the competent agricultural development projects in Sudan, which aims to bridge the country's needs and access to self-sufficiency. This study was aimed to provide policy recommendations that would help the Sudanese sugarcane industry administration to stabilize the price level and reduce cost of production and thereby increase tenants, income and their welfare.

\section{Objective of the Study}

The general objective was to measure total factor productivity changes in Kenana sugar Company and Sudanese Sugar Company factories in the Sudan, to work out technical efficiency index for each of the Sudanese sugar factories and determine the efficiency levels for eight periods starting from 2000 and ending in 2007 and to measure the performance changes over time in Sudanese sugar cane factories. This meant that the study would have little to say about property rights, principals and agents, incentive mechanisms competition versus monopoly, and private versus public provision and so on [7].

\section{The specific objectives of the study were as}

-To provide current information on technical change and efficiency of the sugarcane industry;

-To review and evaluate the enter-firm and intra-firm performance of the sugar industry over time; using panel and time series data

-To compare the competitiveness of Kenana Sugar Company with that of Sudanese sugar Company

-To identify some critical parameters to improve the total factor productivity and competitiveness of the sugarcane industry

\section{Methodology}

This study is concerned with the measurement of changes in economic performance of Kenana and Sudanese Sugar factories over time. The emphasis was to measure change in productivity over time. The particular measure of productivity used was based on distance function namely input oriented Malmquist index, using data envelopment analysis computer program DEAP Version 2.1. Inputoriented measure looking for a minimal proportional of an input vector, given an output vector

\section{Total factor productivity model}

Nonparametric linear programming techniques were employed to decompose each factory productivity index into two components, one measuring change in efficiency and the other measuring technical change or equivalently change in the frontier technology. The equation could be written as:

$$
M_{i}^{t+1}\left(y^{t+1}, x^{t+1}, y^{t}, x^{t}\right)=\frac{D_{i}^{t+1}\left(y^{t+1}, x^{t+1}\right) *}{D_{i}^{t}\left(y^{t}, x^{t}\right)}\left[\frac{D_{i}^{t}\left(y_{i}^{t+1}, x^{t+1}\right)}{D_{i}^{t+1}\left(y^{t+1}, x^{t+1}\right)} * \frac{D_{i}^{t}\left(y^{t}, x^{t}\right)}{D_{i}^{t+1}\left(y^{t}, x^{t}\right)}\right]
$$

Quotient outside the brackets measured the change in technical efficiency and the ratios inside the brackets measured the shift in the frontier between period's $t$ and $t+1$.

If the value of Malmquist index or any component is less than 1, it denotes improvement in the performance, whereas value greater than 1 denotes deterioration in its performance.

The technical efficiency could be further decomposed to become

$$
\mathrm{M}_{\mathrm{i}}^{\mathrm{t}+1}\left(\mathrm{y}^{\mathrm{t}+1}, \mathrm{x}^{\mathrm{t}+1}, \mathrm{y}^{\mathrm{t}}, \mathrm{x}^{\mathrm{t}}\right)=\mathrm{PECH}^{*} \mathrm{SECH} * \mathrm{TECHCH}
$$

In which $\mathrm{TECHCH}$ represented technical change, $\mathrm{PECH}$ represented pure efficiency change, and SECH represented scale change. The scale change and pure efficiency change components were decompositions of efficiency change calculated relative to constant returns to scale: $\mathrm{EFFCH}=\mathrm{PECH}{ }^{\star} \mathrm{SECH}$. EFFCH referred to efficiency change calculated under constant returns to scale, and $\mathrm{PECH}$ was efficiency change calculated under variable returns to scale [8]. The productivity index may be expressed in terms of the following distances along the $\mathrm{x}$-axis in Figure 1 as follows

$$
M_{i}^{t+1}\left(y^{t+1}, x^{t+1}, y^{t}, x^{t}\right)=\frac{\left(\frac{o b}{o a}\right)}{\left(\frac{o d}{o e}\right)}\left[\left(\frac{o a}{o c}\right)\left(\frac{o f}{o e}\right)\right]^{\frac{1}{2}}
$$

where $(0 \mathrm{~b} / 0 \mathrm{a}) /(\mathrm{od} / \mathrm{oe})$ denotes the ratio of the Farrell measures of technical efficiency, and the last part is the geometric mean of the shifts in technology at yt and yt+1. It is to be noted that, the shifts in technology are to be measured locally for the observation at $t$ and $t+1$. This implies that the whole technology need not behave uniformly and the technological regress is possible Scale inefficiency change would 
not indicate whether the change was due to operation of the decision making unit (DMU) at increasing returns to scale (IRS) or at decreasing returns to scale (DRS) or at constant return to scale (CRS) To know this technical efficiency for the

with, DMU, the estimated input-orientated efficiency score $\hat{\theta}_{i}$ under constant returns to scale is given by solving the following linear programming model:

$$
\min _{\lambda, \hat{\theta}_{i}} \hat{\theta}_{i}
$$

$$
\begin{aligned}
& \text { Subject to }-\mathrm{y}_{\mathrm{i}}+\mathrm{Y} \lambda \geq 0 \\
& \hat{\theta}_{i} x_{i}-X \lambda \geq 0 \\
& \mathrm{Y} \lambda \geq 0
\end{aligned}
$$

where $\mathrm{X}$ and $\mathrm{Y}$ are matrices of the inputs and outputs, respectively, of all observed (N) DMUs; $x_{i}$ and $y_{i}$ are respectively, the input and output vectors of the ith DMU; $\lambda$ is a $\mathrm{N}$ x 1 vector of constants; $\theta_{i}$ is the technical efficiency of the ith DMUs, bounded by 0 and 1 , with a value of 1 indicating a technically efficient DMU.

The variable returns to scale (VRS) data envelopment analysis (DEA) model is obtained by adding the constraint $\mathrm{N}_{1}{ }^{\mathbb{\lambda}} \lambda=1$, where $\mathrm{N}_{1}$ is a $N^{*} 1$ vector of ones. This is a convexity constraint ensuring that a firm is benchmarked against firms of a similar size. Scale efficiency is obtained as the ratio of the CRS efficiency measure (technical efficiency) to the VRS measure (pure technical efficiency). DEA under decreasing returns to scale (DRS) is obtained by adding the constraint $\mathrm{N}_{1}{ }^{\prime} \lambda=1$. If the two scores are different, then the ith DMU operates under increasing returns to scale (IRS).

\section{Type of data}

The data used were a complete panel of annual observation on Kenana and Sudanese sugar companies decision making units (DMUs) of 8 years (2000-2007). The data were normalized by the gross domestic product (GDP) deflator, and calculating the natural log so as to avoid variations in data.

The method used input cost for all (DMUs) according to the production functions:

$$
y=f\left(x_{1}, x_{2}, x_{3}, x_{4}\right)
$$

$\mathrm{y}=$ output of sugar in SDG.

$\mathrm{x}_{1}=$ cane cost in SDG

$\mathrm{x}_{2}=$ labour cost in SDG.

$\mathrm{x}_{3}=$ material cost in SDG.

$\mathrm{x}_{4}=$ other expenses in SDG.

The time frame of this study was 2000-2007 and the information needed consisted of the following:

1. Detailed cost of sugarcane industry (input total cost).

2. Value of output (sugarcane).

\section{Data analysis}

Data were analysed using statistical package for social sciences (SPSS) software. The back word regression to test the relationship between TFP change and different input variables in accordance to the following model:

Where: TFP $=$ total factor productivity change

$\mathrm{B}_{0}=$ constant.

$\mathrm{B}_{1}, \mathrm{~B}_{2}, \mathrm{~B}_{3}, \mathrm{~B}_{4}$, = regression coefficients

$\mathrm{TFP}=\mathrm{B}_{0}+\mathrm{B} 1 \mathrm{X} 1+\mathrm{B} 2 \mathrm{X} 2+\mathrm{B} 3 \mathrm{X} 3+\mathrm{B} 4 \mathrm{X} 4$

$\mathrm{x}_{1}, \mathrm{x}_{2} \mathrm{x}_{3}, \mathrm{x}_{4}, \mathrm{x}_{5}=$ Cane cost, labour cost, material cost , and other expenses, respectively

\section{Results and Discussion}

The results of this analysis were shown in Tables 4 and 5 and Figures 2 and 3 to compare Kenana and Sudanese Sugarcane Factories during the same period 2000-2007. Table 4 shows average annual growth rate TECH, EFFCH, and TFPCH over the whole period of 2000-2007. There was a negative average annual productivity at the beginning i.e., the TFP value was greater than one at seasons 2000-01 and 2001-02 and gave positive change .i.e., the TFP value was less than one from season 2002 to 2003, it was negative again in seasons 2003 to2006 and positive in season (2006-07). TFP growth recorded by these sugar factories were estimated to range from low of $-12.8 \%$ in $2004-05$ to a high of $18.3 \%$ in 2006-07. TECH in average means ranged from $20.5 \%$ in season 2006 -

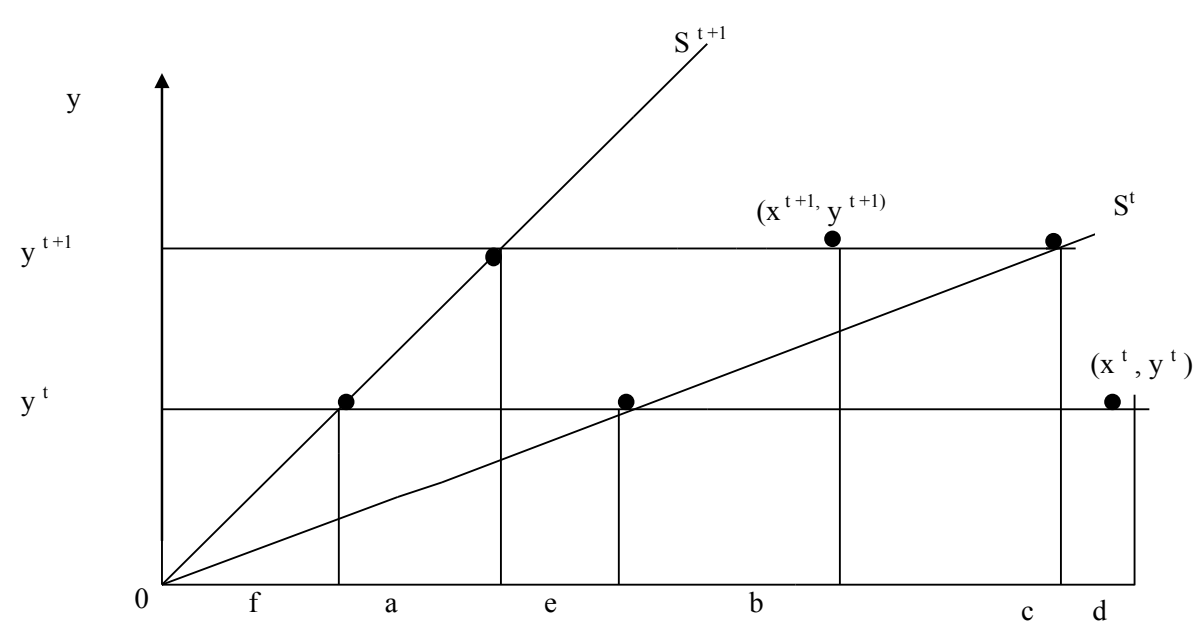

Figure 1: The input based Malmquist productivity index. 
07) to $-15.3 \%$ in $2001-02$. EFFCH ranged from $10 \%$ in season 2001 $02)$ to $-5.5 \%$ in $2002-03$ ). The separate rates of growth of TECH and EFFCH had to be combined in order to identify the source of TFP growth. Furthermore, the TFP growth in the whole period 2000-2007 was $-0.2 \%$; all of the change in TFP was mainly due to EFFCH. In fact $\mathrm{TECH}$ in the same period was $0.5 \%$, while the average contribution of EFFCH for the whole period was $-0.7 \%$ and this was mainly due to scale inefficiency as shown in Table 4 and Figure 2. The interpretation of Kenana and Sudanese Sugarcane factories experienced inward shift in their production frontiers over the whole period, due to productivity growth. For Gunied and Sinnar, TFPCH was $-0.3 \%$ and $-3.2 \%$ respectively. TECH, as a component of TFP, as measured by inputoriented Malmquist index, was the main problem facing Gunied by $-0.4 \%$, and SECH was the main problem facing Sinnar by $-3.8 \%$, while the EFFCH contribute $1 \%$ and $-3.8 \%$ and TECH $0.5 \%$ respectively and the PEFCH had positive values as shown in Table 5 and Figure 3. The efficiency changes component was calculated relative to the constantreturn to scale (CRS) and (VRS) technology and was decomposed into PEFCH component and SEFCH component which captures change in the deviation between the VRS and CRS technology. Table 6 shows that in the 8 years Sinnar and Hajar Assalaya scale inefficiency was mainly due to operating at IRS whereas Kenana, Gunied and New Halfa were operating at CRS. Table 7 shows that total factor productivity decreased

\begin{tabular}{|c|c|c|c|c|c|}
\hline Year & Effch & Techch & Pech & Sech & Tfpch \\
\hline $2000 / 2001$ & 1.05 & 1.025 & 1 & 1.05 & 1.076 \\
\hline $2001 / 2002$ & 0.9 & 1.153 & 0.98 & 0.918 & 1.037 \\
\hline $2002 / 2003$ & 1.055 & 0.853 & 1.02 & 1.034 & 0.9 \\
\hline $2003 / 2004$ & 1.053 & 0.969 & 1 & 1.053 & 1.02 \\
\hline $2004 / 2005$ & 1.001 & 1.126 & 0.999 & 1.002 & 1.128 \\
\hline $2005 / 2006$ & 0.976 & 1.104 & 0.984 & 0.991 & 1.077 \\
\hline $2000 / 2007$ & 1.027 & 0.795 & 1.017 & 1.01 & 0.817 \\
\hline G.Means & 1.007 & 0.995 & 1 & 1.007 & 1.002 \\
\hline
\end{tabular}

Table 4: Total factor productivity component: Summary of annual means of Kenana and Sudanese Sugarcane plants (2000-2007).

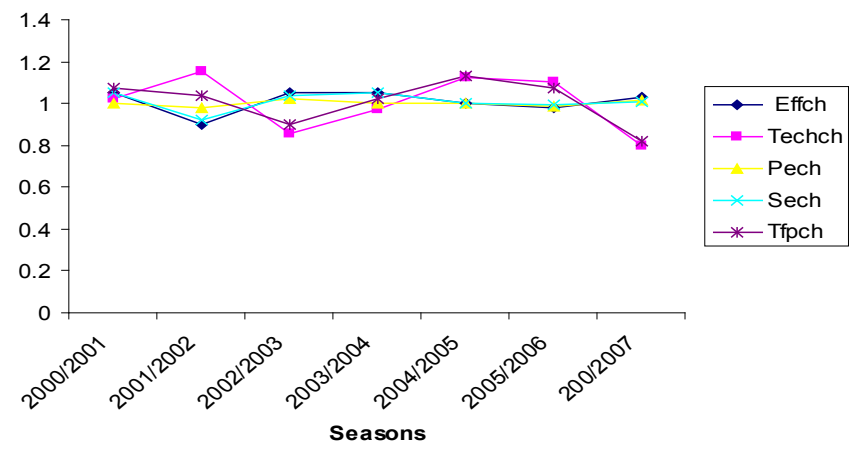

Figure 2: Malmquist index components: Summary of annual means of Kenana and Sudanese Sugar Companies (2000/07).

\begin{tabular}{|c|c|c|c|c|c|}
\hline Plants & Effch & Techch & Pech & Sech & Tfpch \\
\hline Kenana & 1 & 0.987 & 1 & 1 & 0.987 \\
\hline Gunied & 0.999 & 1.004 & 1 & 0.999 & 1.003 \\
\hline New Halfa & 1 & 0.997 & 1 & 1 & 0.997 \\
\hline Sinnar & 1.038 & 0.995 & 1 & 1.038 & 1.032 \\
\hline Hajar Assalaya & 1 & 0.993 & 1 & 1 & 0.993 \\
\hline
\end{tabular}

Table 5: Malmquist index components: Summary means of Kenana and Sudanese Sugar Companies (2000/2007).

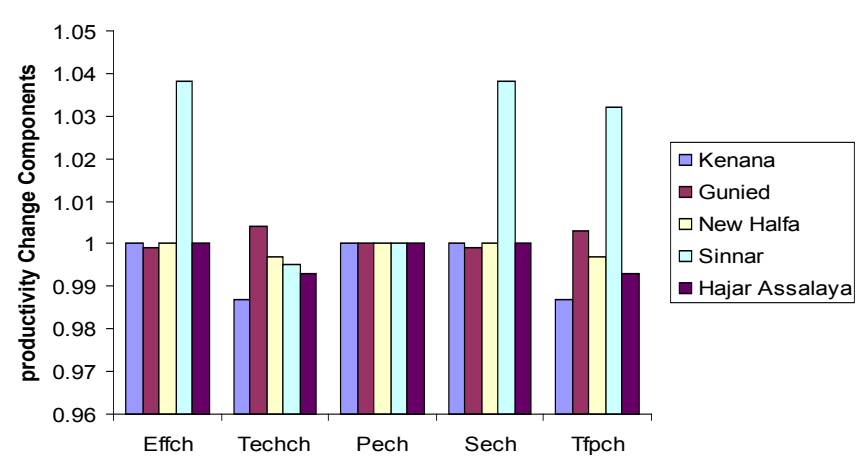

Figure 3: Malmquist index components: Summary means of Kenana and Sudanese Sugar Company factories (2000/2007).

\begin{tabular}{|c|c|c|c|c|}
\hline Plants & Crste & Vrste & Scale & Scale Returns \\
\hline Kenana & 1 & 1 & 1 & Crs \\
\hline Gunied & 1 & 1 & 1 & Crs \\
\hline New Halfa & 1 & 1 & 1 & Crs \\
\hline Sinnar & 0.772 & 1 & 0.772 & Irs \\
\hline Hajar Assalaya & 0.998 & 1 & 0.998 & Irs \\
\hline G. mean & 0.954 & 1 & 0.954 & \\
\hline
\end{tabular}

Note: Crste $=$ Technical efficiency from CRS DEA, vrste $=$ Technical efficiency from VRS DEA, Scale $=$ Scale efficiency $=$ Crste $/$ Vrste

Table 6: Efficiency Summary of Sudanese sugar factories return (2000/2007).

\begin{tabular}{|c|c|c|c|c|}
\hline \multirow{2}{*}{ Model } & \multicolumn{2}{|c|}{ Coefficients } & \multirow{2}{*}{ t } & \multirow{2}{*}{ Sig. } \\
\cline { 2 - 3 } & $\mathbf{B}$ & Std. error & & \\
\hline $1^{\text {st }}$ Constant & -0.142 & 1.227 & -0.166 & 0.908 \\
\hline Cane cost & -0.111 & 0.166 & -0.667 & 0.51 \\
\hline Labor cost & $-7.97 \mathrm{E}-02$ & 0.076 & -1.051 & 0.302 \\
\hline Material & $9.55 \mathrm{E}-02$ & 0.066 & 1.456 & 0.156 \\
\hline Other expenses & 0.205 & 0.037 & 5.582 & 0 \\
\hline $2^{\text {nd }}$ Constant & -0.934 & 0.307 & -3.04 & 0.005 \\
\hline Labor cost & -0.114 & 0.056 & -2.037 & 0.05 \\
\hline Material & $9.00 \mathrm{E}-02$ & 0.064 & 1.396 & 0.173 \\
\hline Other expenses & -205 & 0.036 & 5.629 & 0 \\
\hline $3^{\text {rd }}$ Constant & -0.738 & 0.277 & -2.661 & 0.012 \\
\hline Labor cost & $-5.03 \mathrm{E}-02$ & 0.033 & -1.528 & 0.136 \\
\hline Other expenses & 0.202 & 0.037 & 5.488 & 0 \\
\hline $4^{\text {th }}$ Constant & -1.039 & 0.199 & -5.228 & 0 \\
\hline Other expenses & 0.185 & 0.036 & 5.17 & 0 \\
\hline
\end{tabular}

Table 7: Sudan Sugar factories variable coefficients a (2000-2007).

as labour cost increased, while total factor productivity increased as other expenses increased. The other expenses were significant at less than one percent level of significance.

\section{Conclusions}

- In this study, improvements in productivity occur when the value of Malmquist index or any component was less than unity; it is a source of improvement in productivity.

- In the analysis of Sudanese sugar factories (2000-2007), the innovation was improving through the gradual and slow decline of negative productivity change over time.

- Furthermore, all the change in TFP was mainly due to EFFCH; in fact, TECH in the whole period was only $5 \%$, while the contribution of EFFCH was $-0.7 \%$. 
- The estimate of Sudanese sugarcane factories TFPCH was $-0.2 \%$ for the whole period. The major contributor to this negative EFFCH was Sinnar factory contribution at an average annual rate of $-3.2 \%$ over the period of this study

- During the 8 years Sinnar and Hajar Assalaya scale inefficiency was mainly due to operating at increasing return to scale (IRS)

- Kenana, Gunied and New Halfa scale inefficiency was due to constant return to scale (CRS).

- Finally, substantial improvement in knowledge of productivity, efficiency and innovation in technology is required to increase sugar factories productivity.

\section{Recommendations}

- Technical package should be put in consideration.

- In depth and oriented training will lead to good productivity.

- High consideration should be taken towards sugarcane research, training in different Sudanese sugar factories.

The policy maker in the Sudanese sugar factories and managers of other sugar factories should make efforts to benefit from added value of sugar industry through downstream processes of sugarcane byproduct such as molasses and bagasse, which could be utilized usefully for animal feed, and production of energy and ethanol.

\section{References}

1. Fare R (1992) Productivity changes in Swedish pharmacies : A non-parametric Malmquist approach Springer.

2. Elsaid SA (1999) Agriculture and Globalization Challenges. Strategic Study Centre-Khartoum, Sudan.

3. Development A O f A (2008) Sugarcane Production in the World .Yearbook of the Arab Agricultural Censuses pp: 27-28.

4. Organisation IS (2009) World production and consumption sugar.

5. Bravo U, Rieger L (1991) Dairy farm efficiency measurement using stochastic frontiers and eoclassical duality. American Journal of Agricultural Economics 73: 421-428.

6. Fare R.S, Grosskopf, Lovell CK (1994) Production frontiers. Cambridge University Press.

7. Coelli T (1996) A guide to DEAP version 2.1: a data envelopment analysis (computer) program. Armidale: University of New Engaland pp: 49.

8. Gorton M, Davidova S (2004) Farm productivity and efficiency in the CEE applicant countries: a synthesis of results. Agricultural economics 30: 1-16. 